\title{
KILAT
}

Vol. 10, No. 1, April 2021, P-ISSN 2089-1245, E-ISSN 2655-4925

DOI: https://doi.org/10.33322/kilat.v10i1.1176

\section{Perbandingan Data Hasil Metode B\&W dan GWC untuk Klasifikasi Slagging Abu Batu Bara LRC}

\author{
Denny Murdany Muchsin \\ PT PLN (Persero) \\ d3nny354@gmail.com \\ denny.murdany@pln.co.id
}

\begin{abstract}
Slagging classification is generally listed in coal COA in coal trading transactions using one of the methods of determining slagging classification so that coal is ensured boiler friendly (low/medium classification). The paper aims to prove the tendency of two methods of determining slagging classification ( $B \& W$ and $G W C$ ) on the results of certain classifications in LRC coal. The research method uses a quantitative method by collecting LRC coal COA data on a coal-fired steam power plant for a year of coal receipt (81 lots) issued by a laboratory that has been accredited by KAN (National Accreditation Committee). According to the method of GWC, ashes of entire lots are classified as LRC ash. While the method of B\&W, there are 62 lots of ash classified as lignitic ash and 19 lots of ash classified as bituminous ash. This research has shown that the GWC method shows 79 lots of ash (97.53\%) has low and medium classification and 2 lots of ash (2.47\%) have a high classification; the method from B\&W shows 19 lots of ash (23.46\%) has a low classification and 62 lots of ash (76.54\%) has a severe classification.
\end{abstract}

Keywords: slagging, George Waterhouse Consultants, Babcock \& Wilcox

\begin{abstract}
ABSTRAK
Klasifikasi slagging umumnya dicantumkan dalam COA batu bara dalam transaksi jual-beli batu bara dengan menggunakan salah satu metode penentuan klasifikasi slagging sehingga batu bara dipastikan boiler friendly (klasifikasi low/medium). Penulisan bertujuan untuk membuktikan kecenderungan dua metode penentuan klasifikasi slagging (B\&W dan GWC) pada hasil klasifikasi tertentu pada batu bara LRC. Metode penelitian menggunakan metode kuantitatif dengan mengumpulkan data COA batu bara LRC pada suatu PLTU selama setahun penerimaan batu bara (81 lot) yang diterbitkan oleh laboratorium yang telah terakreditasi KAN (Komite Akreditasi Nasional). Menurut metode dari GWC, abu seluruh lot termasuk abu LRC. Sedangkan metode dari $B \& W$, terdapat 62 lot abunya tergolong abu lignitic dan 19 lot abunya tergolong abu bituminous. Pada tulisan ini telah menunjukkan hasil bahwa metode dari GWC menunjukkan 79 lot abunya (97,53\%) memiliki klasifikasi Low dan Medium dan 2 lot abunya (2,47\%) memiliki klasifikasi High; metode dari B\&W menunjukkan 19 lot abunya $(23,46 \%)$ memiliki klasifikasi Low dan 62 lot abunya (76,54\%) memiliki klasifikasi Severe.
\end{abstract}

Kata kunci: slagging, George Waterhouse Consultants, Babcock \& Wilcox 


\section{PENDAHULUAN}

Indonesia sebagai negara berkembang masih sangat bergantung pada pembangkit termal PLTU berbahan bakar batu bara setidaknya hingga sepuluh tahun ke depan. Hal ini dapat diketahui dari data bauran energi, bahan bakar batu bara masih memiliki kontribusi energi listrik lebih dari $50 \%$ dari seluruh energi listrik yang diproduksi untuk kepentingan umum se-Indonesia. Berdasarkan data keuangan PLN tiga tahun terakhir (2017-2019), pembelian bahan bakar dan pelumas memiliki komposisi $42,4 \%$ s.d. $44,5 \%$ dari seluruh biaya operasional dimana pembelian bahan bakar batu bara berada pada range $33,7 \%$ - 36,3\% dari biaya pembelian bahan bakar dan pelumas. Hal ini menunjukkan bahwa efisiensi penggunaan bahan bakar menjadi sesuatu hal yang tidak bisa ditawartawar. Oleh karena itu, tara kalor menjadi salah satu KPI (Key Performance Indicator) unit pelaksana pembangkit supaya efisiensi tersebut dapat diukur dan dievaluasi. Salah satu variabel yang berpengaruh terhadap pencapaian KPI tersebut adalah kualitas batu bara berupa slagging factor atau slagging indice yaitu besaran potensi batu bara untuk membentuk slagging di dalam boiler PLTU. [1] [2] [3] [4]

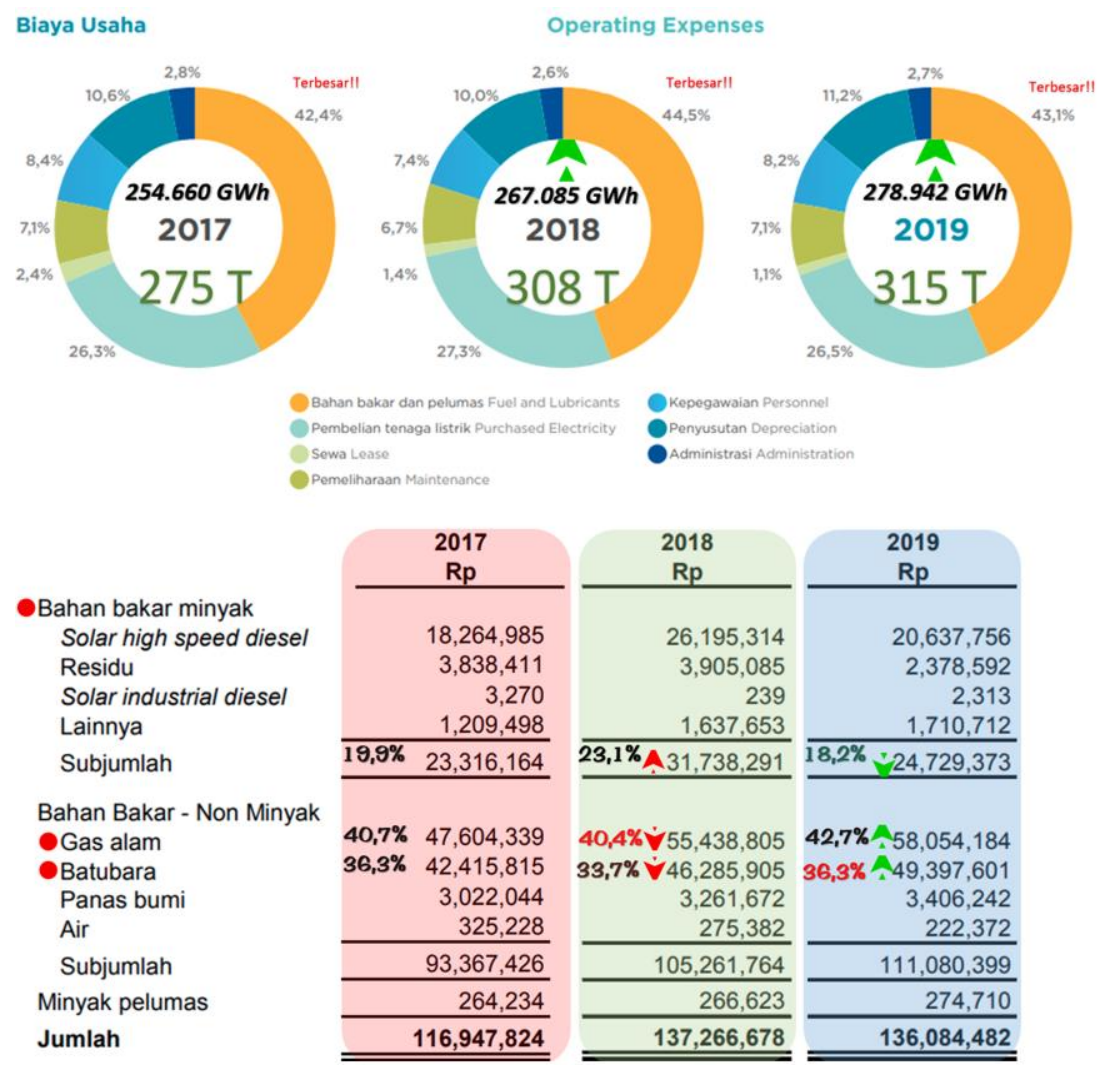

Gambar 1. Komposisi Biaya Operasional dan Biaya Bahan Bakar dan Pelumas PLN tiga tahun terakhir

Telah banyak peneliti yang mempelajari slagging indice untuk menemukan korelasi yang sesuai baik dari titik leleh, viskositas abu dalam boiler, maupun partikel abu itu sendiri. Informasi karakteristik slagging abu tersebut sangat membantu dalam hal memprediksi besaran potensi slag sticking di dalam boiler. Komponen mineral dalam abu batu bara tidak sama sehingga diperlukan kajian oleh pengguna batu bara untuk menyimulasikan pertumbuhan slag. Pada rasio basa/asam dan rasio $\mathrm{SiO}_{2} / \mathrm{Al}_{2} \mathrm{O}_{3}$ yang sama dengan rasio $\mathrm{CaO} / \mathrm{Fe}_{2} \mathrm{O}_{3}$ yang berbeda menunjukkan hasil bahwa pada rasio $\mathrm{CaO} / \mathrm{Fe}_{2} \mathrm{O}_{3}$ yang rendah mengakibatkan kenaikan AFT (Ash Fusion Temperature). Oleh karena itu, kurang tepat ketika potensi slagging hanya diindikasikan oleh rasio basa/asam. Pada penelitian 


\section{KILAT}

Vol. 10, No. 1, April 2021, P-ISSN 2089-1245, E-ISSN 2655-4925

DOI: https://doi.org/10.33322/kilat.v10i1.1176

yang dilakukan oleh Nor Jauhara Sophia et. al. terhadap delapan buah sampel batu bara subbituminous, formula B/A ratio menunjukkan hasil yang selalu selaras dengan formula Ash Fusion Temperature. Ketika B/A ratio menunjukkan potensial slagging yang low/medium, maka formula AFT pun menunjukkan hal yang sama. Hal tersebut konsisten pada delapan sampel batu bara subbituminous yang tergolong LRC. [5] [6] [7]

Babcock \& Wilcox (selanjutnya disingkat B\&W) sebagai perusahaan manufaktur boiler yang berasal dari negara USA telah mengembangkan beberapa slagging indice untuk berbagai aspek pada desain boiler. Slagging indice akan menentukan kriteria desain furnace dan area radiasi lainnya. Karakteristik deposisi diklasifikasikan menjadi empat kategori yaitu: Low, Medium, High, dan Severe. Indeks tersebut dihitung berdasarkan analisis sulphur content dan abu (ash analysis: mineral composition \& ash fusion temperature) menggunakan standar ASTM. Indeks-indeks ini juga dapat digunakan secara komparatif untuk memberi peringkat batu bara sehubungan dengan potensi slagging dan fouling mereka ketika mengevaluasi pasokan batu bara baru. Dalam penentuan slagging indice, secara garis besar formulanya dibagi atas dua jenis abu: abu lignit dan abu bituminous. Pada beberapa pembangkit besar milik PLN, penentuan slagging indice dan klasifikasinya menggunakan metode dari B\&W. [8]

George Waterhouse Consultants Ltd. (selanjutnya disingkat GWC) sebagai perusahaan konsultan berasal dari UK pada bidang utilisasi bahan bakar padat, cair, dan gas, menyampaikan juga metode penentuan slagging indice dan klasifikasi slagging di dalam handbook yang mereka telah susun. Slagging indice dihitung berdasarkan analisis sulphur content dan abu (mineral composition) tanpa menyebutkan standar analisis yang digunakan. Dalam penentuan slagging indice, secara garis besar formulanya dibagi atas dua jenis abu: abu LRC dan abu bituminous. Sebagian besar pembangkit milik PLN menggunakan metode yang disampaikan oleh GWC untuk menentukan slagging indice/factors dan klasifikasinya. [9]

\section{METODE PENELITIAN}

Proses penelitian ini meliputi pengambilan data sekunder, pengolahan data, dan analisis statistik. Penelitian ini dilakukan pada PLTU (Pusat Listrik Tenaga Uap) Sebalang 2 x 115 MW yang berlokasi di Lampung Selatan, Provinsi Lampung. PLTU berbahan bakar batu bara jenis LRC (Low Rank Coal) ini disuplai batu baranya dari lebih dari satu pemasok dalam negeri dengan nilai tipikal Gross Caloric Value $4.200 \mathrm{kKal} / \mathrm{kg}$ (as received basis).

\subsection{Pengambilan Data Sekunder}

Data-data sekunder yang digunakan di dalam penelitian ini adalah Total Sulfur (\%, db), Ash Analysis, dan AFT. Data tersebut diperoleh dari dokumen COA unloading pada setiap lot penerimaan yang diterbitkan oleh lembaga surveyor independen yang telah terakreditasi KAN (Komite Akreditasi Nasional). Data sekunder yang diambil berasal dari proses penerimaan batu bara oleh PLTU Sebalang selama tahun 2018 sebanyak 81 lot penerimaan.

Pengambilan sampel oleh surveyor independen dilakukan di jetty PLTU Sebalang dengan jenis non-probability sampling secara manual di belt conveyor bergerak (kondisi C menurut ASTM D2234). Metode sampling ini dilakukan hanya jika mechanical sampling terpaksa tidak bisa dilakukan oleh karena belum tersedia atau kondisi peralatan sampling-nya rusak. [10] [11]

Pengujian total sulphur oleh surveyor independen dilakukan menggunakan metode ASTM D4239 (sulphur content) yaitu metode pembakaran dan dianalisis dengan infrared absorption detector. Adapun pengujian komposisi mineral pada abu batu bara menggunakan metode ASTM D3682 yaitu menentukan komposisi (mayor dan minor) komponen pembentuk abu batu bara dengan 
prinsip Atomic Absorption Spectroscopy (spektroskopi serapan atom). Pada pengujian yang lain yaitu AFT menggunakan metode ASTM D1857 yaitu memanaskan sampel berbentuk cone hingga mencapai temperatur yang mengubah bentuk cone dengan dialirkan gas tertentu supaya tercapai reducing atmosphere dan oxidizing atmosphere. [12] [13] [14]

\subsection{Pengolahan Data}

Semua tahapan penentuan slagging indice dan klasifikasi slagging tersebut dilakukan dengan dua metode (B\&W dan GWC) pada data tiap-tiap lot penerimaan batu bara sehingga mendapatkan 81 data slagging indice dan klasifikasi slagging dari tiap-tiap metode.

\subsubsection{Metode dari $B \& W$}

Data yang dibutuhkan dari COA (Certificate of Analysis) adalah sulphur content (dry basis), Hemispherical Temperature (reducing \& oxidizing atmosphere), Initial Deformation Temperature (reducing \& oxidizing atmosphere), komposisi mineral dalam abu $\left(\mathrm{SiO}_{2}, \mathrm{CaO}, \mathrm{Al}_{2} \mathrm{O}_{3}, \mathrm{TiO}_{2}, \mathrm{Fe}_{2} \mathrm{O}_{3}\right.$, $\mathrm{K}_{2} \mathrm{O}, \mathrm{MgO}, \mathrm{Na}_{2} \mathrm{O}$ ).

Tahapan pertama adalah menentukan jenis abu secara formula sebagai berikut:

- Jika $\mathrm{Fe}_{2} \mathrm{O}_{3}>\mathrm{CaO}+\mathrm{MgO}$, maka tergolong abu Bituminous.

- Jika $\mathrm{Fe}_{2} \mathrm{O}_{3}<\mathrm{CaO}+\mathrm{MgO}$, maka tergolong abu Lignit.

Tahap kedua adalah menghitung slagging indice $\left(R_{S}\right.$ atau $\left.R_{S}^{*}\right)$ secara formula sebagai berikut

- Bagi abu Bituminous: $R_{S}=\frac{B}{A} x S$

yang B sebagai jumlah persentase komposisi mineral bersifat basa $\left(\mathrm{CaO}+\mathrm{MgO}+\mathrm{Fe}_{2} \mathrm{O}_{3}+\right.$ $\left.\mathrm{Na}_{2} \mathrm{O}+\mathrm{K}_{2} \mathrm{O}\right)$; A sebagai jumlah persentase komposisi mineral bersifat asam $\left(\mathrm{SiO}_{2}+\mathrm{Al}_{2} \mathrm{O}_{3}\right.$ $+\mathrm{TiO}_{2}$ ); dan $\mathrm{S}$ sebagai nilai persentase total sulfur pada dry basis

- Bagi abu Lignit: $R_{S}^{*}=\frac{H T_{\text {terbesar }}+\left(4 x I D T_{\text {terkecil }}\right)}{5}$

(2)

yang $\mathrm{HT}_{\text {terbesar }}$ sebagai nilai Hemispherical Temperature terbesar di antara kondisi reducing atmosphere dan oxidizing atmosphere; IDT $_{\text {terkecil }}$ sebagai Initial Deformation Temperature terkecil di antara kondisi reducing atmosphere dan oxidizing atmosphere.

Tahap ketiga adalah menentukan klasifikasi slagging-nya berdasarkan jenis abu dan nilai slagging indice-nya:

- Bagi abu Bituminous: Low jika $\mathrm{R}_{\mathrm{s}}<0,6$; Medium jika $0,6<\mathrm{R}_{\mathrm{s}}<2$; High jika $2<\mathrm{R}_{\mathrm{s}}<2,6$; Severe jika $\mathrm{R}_{\mathrm{s}}>2,6$.

- Bagi abu Lignit: Low jika $R_{S}^{*}>2450 ;$ Medium jika $2250<R_{S}^{*}<2450$; High jika $2100<$ $R_{S}^{*}<2250 ;$ Severe jika $R_{S}^{*}<2100$.

Hasil pengolahan data dengan metode dari B\&W dapat dilihat pada Tabel 1: 


\section{KILAT}

Vol. 10, No. 1, April 2021, P-ISSN 2089-1245, E-ISSN 2655-4925

DOI: https://doi.org/10.33322/kilat.v10i1.1176

Tabel 1. Hasil Pengolahan Data Menggunakan Metode dari B\&W

\begin{tabular}{|c|c|c|c|c|c|c|c|c|c|c|c|c|c|c|c|c|}
\hline No. & 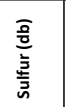 & 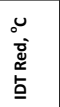 & 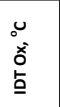 & 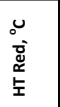 & 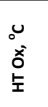 & ఫ్లే & ஓ & $\stackrel{\circ}{\stackrel{\infty}{2}}$ & 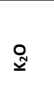 & 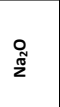 & 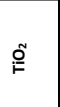 & ஸ̃ & $\frac{0_{0}^{0}}{\mathbb{\alpha}}$ & Jenis Abu & $\begin{array}{c}\text { Slagging } \\
\text { Indice }\end{array}$ & $\begin{array}{l}\text { Klasifiks } \\
\text { Slagging }\end{array}$ \\
\hline 1 & 0,25 & 1240 & 1300 & 1260 & 132 & 10,11 & 15,59 & 1,78 & 0,39 & 0,56 & 0,83 & 44,83 & 18,11 & Lignitic Ash & $1.452,00$ & Severe \\
\hline 2 & 0,25 & 1250 & 1310 & 1270 & $133 \mathrm{C}$ & 10,45 & 17,99 & 5,90 & 0,32 & 0,29 & 0,92 & 37,9 & 18,82 & Lignitic Ash & $1.463,60$ & Severe \\
\hline 3 & 0,32 & 1270 & 1330 & 1290 & $135 \mathrm{C}$ & 11,26 & 17,17 & 1,22 & 0,21 & 0,36 & 1,86 & 36,72 & 25,31 & Lignitic Ash & $1.486,80$ & Severe \\
\hline 4 & 0,26 & 1170 & 1230 & 1190 & $125 \mathrm{C}$ & 12,53 & 22,96 & 2,54 & 0,34 & 0,35 & 0,88 & 28,8 & 24,70 & Lignitic Ash & $1.370,80$ & Severe \\
\hline 5 & 0,33 & 1260 & 1320 & 1280 & $134 \mathrm{C}$ & 10,41 & 22,90 & 1,46 & 0,35 & 0,58 & 2,08 & 25,38 & 25,74 & Lignitic Ash & $1.475,20$ & Severe \\
\hline & 0,20 & 1160 & 1220 & 1180 & 124 & 15,36 & 30,80 & 2,77 & 0,34 & 0,41 & 1,10 & 17,40 & 23,90 & Lignitic Ash & $1.359,20$ & Severe \\
\hline 7 & 0,21 & 1230 & 1290 & 1250 & $131 \mathrm{C}$ & 13,41 & 27,51 & 2,21 & 0,36 & 0,47 & 0,97 & 26,96 & 18,79 & Lignitic Ash & $1.440,40$ & Severe \\
\hline 8 & 0,29 & 1250 & 1310 & 1270 & $133 \mathrm{C}$ & 13,75 & 16,83 & 2,26 & 0,36 & 0,61 & 2,28 & 34,20 & 21,47 & Lignitic Ash & $1.463,60$ & Severe \\
\hline 9 & 0,20 & 1210 & 1270 & 1230 & $129 \mathrm{C}$ & 14,28 & 20,39 & 2,61 & 0,41 & 0,45 & 0,78 & 35,27 & 17,40 & Lignitic Ash & $1.417,20$ & Severe \\
\hline 10 & 0,26 & 1250 & 1310 & 1270 & 133 & 12,47 & 14,09 & 0,78 & 0,25 & 0,29 & 0,98 & 43,62 & 19,24 & Lignitic Ash & $1.463,60$ & Severe \\
\hline 11 & 0,41 & 1260 & 1320 & 1280 & 134 & 15,63 & 5,19 & 1,05 & $0,0,53$ & $\begin{array}{ll}, 2,17 \\
\end{array}$ & 1,35 & 51,90 & 20,61 & Bituminous Ash & 0,13 & Low \\
\hline 12 & 0,21 & 1200 & 1260 & 1220 & 128 & 13,95 & 14,17 & 2,21 & $0,0,4$ & 0,35 & 0,63 & 34,48 & 25,40 & Lignitic Ash & $\begin{array}{r}1.405,60 \\
\end{array}$ & Severe \\
\hline 13 & 0,21 & 1180 & 1240 & 1200 & 126 & 11,91 & 10,28 & 2, & 0, & $\begin{array}{ll}0,38 \\
, 38\end{array}$ & & 38,96 & 24,33 & Lignitic Ash & $1.382,40$ & Severe \\
\hline 14 & 0 & 1250 & 1310 & 1270 & 133 & 12,96 & 10,18 & & & & & & 23,93 & Bituminous Ash & $0,1.502,40$ & \\
\hline 15 & 0,30 & 1290 & 1350 & 1310 & 137 & 9,82 & $\frac{1,9}{9,9}$ & $\frac{2 i}{2}$ & & & & & 25,02 & Lignitic Ash & $\frac{0,10}{1.510,00}$ & 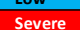 \\
\hline 16 & 0,34 & 1250 & 1310 & 1270 & 133 & 1,67 & 15,7 & $\frac{2,}{1,}$ & 0 & & 1 & 35,68 & 24,01 & Lignitic Ash & $1.463,60$ & Severe \\
\hline 17 & 0,26 & 1290 & 1350 & 1320 & 137 & 15,57 & $\frac{13,9}{13,9}$ & 2 & 0, & & 0,93 & 36,81 & 20,41 & Ligniti & $1.513,60$ & Severe \\
\hline 18 & 0,31 & 1260 & 1320 & 1280 & 134 & 13,53 & 13,16 & $\frac{2,}{1,}$ & , & $\frac{0,2}{0,2}$ & $\frac{0,2}{1,1}$ & 43,48 & $\begin{array}{l}2,414 \\
18,46 \\
\end{array}$ & Lignitic As & $1.475,20$ & Severe \\
\hline$\frac{10}{19}$ & $\begin{array}{l}0,51 \\
0,33 \\
\end{array}$ & 1250 & $\frac{1320}{1310}$ & $\begin{array}{l}1200 \\
1270 \\
\end{array}$ & $\frac{1546}{133}$ & $\begin{array}{l}18,33 \\
18,67 \\
\end{array}$ & $\frac{13,10}{15,81}$ & $\frac{1,05}{2,07}$ & 0,3 & 0,52 & $\frac{1,21}{2,21}$ & 32,75 & 18,83 & Bituminous Ash & 0,23 & Low \\
\hline 20 & 0,32 & 1270 & 1330 & 1290 & 135 & 19,17 & 14,07 & 2,52 & 0,42 & 0,74 & 2,04 & 32,70 & 20,20 & Bituminous Ash & 0,22 & Low \\
\hline 21 & 0,27 & 1260 & 1320 & 1280 & $134 \mathrm{C}$ & 11,10 & 12,23 & 1,21 & 0,18 & 0,31 & 0,96 & 43,09 & 23,50 & Lignitic Ash & $1.475,20$ & Severe \\
\hline 22 & 0,29 & 1270 & 1330 & 1290 & $135 \mathrm{C}$ & 10,74 & 15,12 & 1,02 & 0,27 & 0,29 & 0,78 & 43,01 & 19,07 & Lignitic Ash & $1.486,80$ & Severe \\
\hline 23 & 0,31 & 1300 & 1360 & 1320 & 138 & 12,23 & 6,47 & 1,27 & 0,28 & 0,41 & 1,24 & 43,99 & 24,43 & Bituminous Ash & 0,09 & Low \\
\hline 24 & 0,29 & 1260 & 1320 & 1280 & 134 & 10,86 & 13,92 & 1,4 & 0,2 & 0,51 & 1,25 & 36,90 & 23,70 & Lignitic Ash & $1.475,20$ & Severe \\
\hline 25 & 0,31 & 1250 & 1310 & 1270 & 133 & 14,37 & 17,99 & 0,6 & & & 1,49 & 30,65 & 26,77 & Lignitic Ash & $1.463,60$ & Severe \\
\hline 26 & 0,19 & 1300 & 1360 & 1320 & 138 & 10,42 & 27,9 & & & & 0,61 & 23,6 & 16,12 & Lignitic Ash & $1.521,60$ & Severe \\
\hline 27 & 0,30 & 1180 & 1240 & 1200 & 126 & 13,77 & 11,6 & & & & & & 24,63 & Bituminous Ash & 0,12 & Low \\
\hline 28 & 0,43 & 1230 & 1290 & 1250 & 131 & 10,7 & 7,3 & & & & & 52 & 21,87 & Bitumin & 0,12 & Low \\
\hline 29 & 0, & & 1270 & 1230 & 125 & & & & & & & & 20,4 & Bitum & 0,16 & ow \\
\hline 30 & & & 13 & & & 13,48 & & & & & & & 20, & Lignitic & $\begin{array}{r}1.475,20 \\
\end{array}$ & \\
\hline 31 & & & 132 & & & & & & & & & & 17, & Lignitic Ash & $1.463,60$ & Severe \\
\hline 32 & 0,3 & 12 & 129 & 12 & & 10 & & & & & & & 22, & & $4+40,40$ & Severe \\
\hline & 0, & & & 1280 & 13 & & & & & & & & 25 & & & Severe \\
\hline 34 & 0,2 & 12 & 13 & 1290 & 13 & 12 & 12 & & & & & & 27, & & & Severe \\
\hline 35 & 0,28 & 12 & 131 & 127 & & $\frac{12,4}{10,4}$ & & & & & & & 20,1 & & & Severe \\
\hline 36 & 0,45 & 1230 & 129 & 1250 & 13 & 9,0 & 16,7 & 5, & & & & & 20, & & & Severe \\
\hline 37 & 0,30 & 1270 & 1330 & 1290 & 13 & 6,9 & 24, & & & & & & 16 & & & Severe \\
\hline 38 & 0,39 & 1290 & 135 & 1310 & 13 & 11,0 & 10, & & & & & & 24 & & $1.510,00$ & Severe \\
\hline 39 & 0,28 & 1270 & 133 & 1290 & 13 & 13, & 15,4 & & & & & & 19 & & $1.486,80$ & Severe \\
\hline 40 & 0,29 & 12 & 13 & 1260 & & & 12,2 & & & & & 42 & 24 & & & Severe \\
\hline 41 & 0,2 & 126 & 132 & 1280 & 13 & 14 & 16, & & & & 1, & 39 & 19 & & & Severe \\
\hline 42 & 0,28 & 1260 & 132 & 1280 & 13 & 12 & 15, & 1, & 0, & & 1, & 37 & 24 & Lignitic Ash & $1.475,20$ & Severe \\
\hline 43 & & 125 & 131 & 1270 & 13 & 15, & & 0, & & & 1. & 49 & 22, & Bituminous Ash & 0,09 & Low \\
\hline 44 & 0,26 & 1270 & 133 & 1290 & 13 & 13 & 16,7 & 1, & & & & 35 & 21 & Lignitic Ash & $1.486,80$ & Severe \\
\hline 45 & 0,28 & 1370 & 1430 & 1390 & 145 & $6,2>3$ & 2,45 & 0, & 0,5 & 1,4 & 1 & 55,4 & 29, & Bituminous Ash & 0,04 & Low \\
\hline $\mid 46$ & 0,28 & 1270 & 1330 & 1290 & 135 & 13,91 & 18,21 & 1,27 & 0,30 & 0,35 & 1,20 & 41,7 & 16,58 & Lignitic Ash & $1.486,80$ & Severe \\
\hline 47 & 0,26 & 1250 & 1310 & 1270 & 1336 & 14,70 & 18,22 & $1,8>$ & 0,3 & 0,31 & 1,4 & 35,0 & 21,36 & Lignitic Ash & $1.463,60$ & Severe \\
\hline 48 & 0,5 & 1300 & 1360 & 1320 & 138 & 12,77 & 5,88 & 0,48 & & 0,35 & 0, & 49,94 & 24,21 & Bituminous Ash & 0,14 & Low \\
\hline 49 & 0,26 & 1280 & 1340 & 1300 & 136 & 12,84 & 15,34 & 1,97 & $0: 2$ & & 1, & $39,8<>$ & 19,32 & Lignitic Ash & $1.498,40$ & Severe \\
\hline 50 & 0,26 & 1270 & 1330 & 1290 & 135 & 13,77 & 18,95 & 1,76 & 0,35 & 0,32 & 2,15 & 33,10 & 21,08 & Lignitic Ash & $1.486,80$ & Severe \\
\hline
\end{tabular}

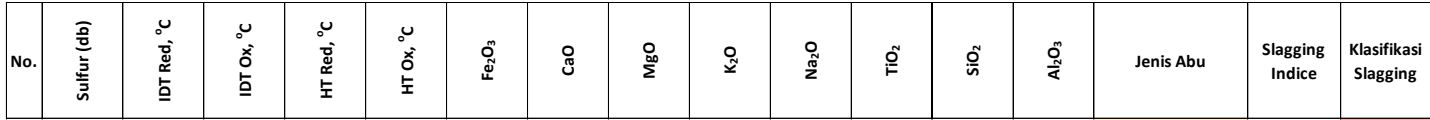

\begin{tabular}{|c|c|c|c|c|c|c|c|c|c|c|c|c|c|c|c|c|}
\hline 51 & 0,37 & 1250 & 1310 & 1270 & 1330 & 11,97 & 6,37 & 0,75 & 0,81 & 0,35 & 1,37 & 47,34 & 24,68 & Bituminous Ash & 0,10 & Low \\
\hline 52 & 0,27 & 1290 & 1350 & 1310 & 1370 & 13,41 & 16,79 & 1,98 & 0,27 & 0,33 & 1,39 & 38,92 & 19,23 & Lignitic Ash & $1.510,00$ & Severe \\
\hline 53 & 0,32 & 1330 & 1390 & 1350 & 1410 & 5,82 & 3,51 & 1,28 & 1,32 & 1,31 & 0,75 & 54,94 & 28,23 & Bituminous Ash & 0,05 & Low \\
\hline 54 & 0,26 & 1290 & 1350 & 1310 & 1370 & 13,59 & 15,41 & 1,75 & 0,50 & 0,41 & 1,55 & 37,57 & 17,67 & Lignitic Ash & $1.510,00$ & Severe \\
\hline 55 & 0,30 & 1260 & 1320 & 1280 & 1340 & 14,39 & 19,52 & 1,60 & 0,33 & 0,44 & 1,87 & 36,06 & 21,81 & Lignitic Ash & $1.475,20$ & Severe \\
\hline 56 & 0,31 & 1330 & 1390 & 1350 & 1410 & 13,40 & 12,22 & 1,59 & 0,28 & 0,43 & 1,93 & 41,60 & 21,56 & Lignitic Ash & $1.556,40$ & Severe \\
\hline 57 & 0,30 & 1260 & 1320 & 1280 & 1340 & 12,53 & 10,62 & 1,45 & 0,25 & 0,51 & 2,15 & 41,17 & 19,59 & Bituminous Ash & 0,12 & Low \\
\hline 58 & 0,26 & 1270 & 1330 & 1290 & 1350 & 10,77 & 14,17 & 1,81 & 0,31 & 0,39 & 2,11 & 36,42 & 23,98 & Lignitic Ash & $1.486,80$ & Severe \\
\hline 59 & 0,25 & 1260 & 1340 & 1290 & 1370 & 13,44 & 20,44 & 2,29 & 0,27 & 0,29 & 2,06 & 33,71 & 19,23 & Lignitic Ash & $1.478,80$ & Severe \\
\hline 60 & 0,40 & 1190 & 1260 & 1210 & 1280 & 20,12 & 8,01 & 1,05 & 0,41 & 0,59 & 2,05 & 41,70 & 21,73 & Bituminous Ash & 0,18 & Low \\
\hline 61 & 0,27 & 1250 & 1350 & 1290 & 1370 & 12,65 & 18,83 & 1,65 & 0,42 & 0,46 & 1,90 & 33,47 & 23,41 & Lignitic Ash & $1.470,80$ & Severe \\
\hline 62 & 0,25 & 1270 & 1350 & 1300 & 1380 & 13,46 & 12,96 & 2,00 & 0,26 & 0,33 & 2,09 & 37,92 & 22,01 & Lignitic Ash & $1.490,40$ & Severe \\
\hline 63 & 0,22 & 1490 & 1526 & 1526 & 1526 & 10,90 & 8,16 & 1,62 & 0,28 & 0,30 & 1,04 & 42,26 & 23,70 & Bituminous Ash & 0,07 & Low \\
\hline 64 & 0,22 & 1260 & 1340 & 1290 & 1370 & 11,15 & 18,75 & 1,97 & 0,29 & 0,55 & 1,14 & 33,61 & 20,67 & Lignitic Ash & $1.478,80$ & Severe \\
\hline 65 & 0,27 & 1310 & 1390 & 1340 & 1420 & 12,37 & 14,77 & 2,06 & 0,29 & 0,57 & 1,46 & 36,86 & 20,87 & Lignitic Ash & $1.536,80$ & Severe \\
\hline 66 & 0,28 & 1250 & 1330 & 1280 & 1350 & 10,70 & 21,77 & 1,21 & 0,39 & 0,48 & 2,44 & 33,89 & 20,92 & Lignitic Ash & $1.467,20$ & Severe \\
\hline 67 & 0,29 & 1250 & 1340 & 1290 & 1360 & 11,45 & 19,37 & 1,77 & 0,43 & 0,62 & 2,38 & 33,14 & 22,94 & Lignitic Ash & $1.470,80$ & Severe \\
\hline 68 & 0,42 & 1200 & 1280 & 1230 & 1310 & 11,52 & 14,24 & 1,44 & 0,46 & 0,97 & 2,23 & 38,78 & 23,82 & Lignitic Ash & $1.409,20$ & Severe \\
\hline 69 & 0,30 & 1260 & 1330 & 1280 & 1360 & 11,09 & 17,76 & 1,51 & 0,44 & 0,73 & 2,48 & 31,87 & 24,73 & Lignitic Ash & $1.475,20$ & Severe \\
\hline 70 & 0,32 & 1270 & 1350 & 1300 & 1380 & 11,14 & 20,41 & 1,97 & 0,51 & 0,59 & 2,04 & 32,22 & 22,95 & Lignitic Ash & $1.490,40$ & Severe \\
\hline 71 & 0,34 & 1250 & 1330 & 1280 & 1350 & 13,58 & 11,88 & 1,30 & 0,75 & 0,63 & 1,45 & 39,38 & 23,96 & Bituminous Ash & 0,15 & Low \\
\hline 72 & 0,48 & 1280 & 1360 & 1310 & 1380 & 12,44 & 8,81 & 1,21 & 1,08 & 0,96 & 1,75 & 40,11 & 27,46 & Bituminous Ash & 0,17 & Low \\
\hline 73 & 0,26 & 1250 & 1320 & 1270 & 1340 & 13,53 & 19,14 & 2,71 & 0,51 & 0,62 & 2,16 & 32,33 & 20,96 & Lignitic Ash & $1.463,60$ & Severe \\
\hline 74 & 0,28 & 1290 & 1360 & 1310 & 1390 & 13,64 & 18,54 & 2,50 & 0,50 & 0,67 & 2,11 & 31,97 & 23,47 & Lignitic Ash & $1.510,00$ & Severe \\
\hline 75 & 0,54 & 1270 & 1340 & 1290 & 1370 & 13,17 & 10,60 & 0,99 & 0,51 & 0,43 & 1,41 & 36,95 & 24,49 & Bituminous Ash & 0,22 & Low \\
\hline 76 & 0,35 & 1200 & 1270 & 1230 & 1290 & 13,31 & 12,47 & 1,53 & 0,44 & 0,96 & 2,21 & 37,50 & 26,00 & Lignitic Ash & $1.409,20$ & Severe \\
\hline 77 & 0,28 & 1280 & 1350 & 1300 & 1370 & 11,13 & 16,54 & 1,74 & 0,50 & 0,63 & 2,44 & 34,81 & 24,96 & Lignitic Ash & $1.498,40$ & Severe \\
\hline 78 & 0,26 & 1260 & 1340 & 1290 & 1370 & 10,72 & 17,60 & 1,72 & 0,45 & 0,60 & 2,03 & 35,15 & 23,70 & Lignitic Ash & $1.478,80$ & Severe \\
\hline 79 & 0,33 & 1250 & 1330 & 1280 & 1360 & 12,62 & 14,43 & 1,09 & 0,47 & 0,66 & 1,28 & 37,46 & 22,79 & Lignitic Ash & $1.467,20$ & Severe \\
\hline 80 & 0,37 & 1270 & 1350 & 1300 & 1370 & 14,76 & 15,71 & 1,68 & 0,56 & 0,62 & 1,68 & 33,92 & 22,69 & Lignitic Ash & $1.490,40$ & Severe \\
\hline 81 & 0,36 & 1250 & 1320 & 1270 & 1340 & 10,52 & 17,95 & 2,04 & 0,40 & 0,94 & 2,07 & 36,78 & 21,46 & Lignitic Ash & $1.463,60$ & Severe \\
\hline
\end{tabular}




\subsubsection{Metode dari GWC}

Data yang dibutuhkan dari COA (Certificate of Analysis) adalah sulphur content (dry basis), dan komposisi mineral dalam abu $\left(\mathrm{SiO}_{2}, \mathrm{CaO}, \mathrm{Al}_{2} \mathrm{O}_{3}, \mathrm{TiO}_{2}, \mathrm{Fe}_{2} \mathrm{O}_{3}, \mathrm{~K}_{2} \mathrm{O}, \mathrm{MgO}, \mathrm{Na}_{2} \mathrm{O}\right)$.

Tahapan pertama adalah menentukan jenis abu berdasarkan klasifikasi batu baranya:

- Abu Bituminous: abu yang berasal dari batu bara bituminous yang berada pada rank antara batu bara sub-bituminous dan batu bara semi-anthracite.

- Abu LRC (Low Rank Coal): abu yang berasal dari batu bara lignit dan batu bara subbituminous yang memiliki high moisture sehingga kalorinya pun rendah.

Tahap kedua adalah menghitung slagging indice $\left(R_{S}\right.$ atau $\left.R_{S}^{*}\right)$ secara formula sebagai berikut

- Bagi abu Bituminous: $R_{S}=\frac{B}{A} x S$

yang B sebagai jumlah persentase komposisi mineral bersifat basa $\left(\mathrm{CaO}+\mathrm{MgO}+\mathrm{Fe}_{2} \mathrm{O}_{3}+\right.$ $\left.\mathrm{Na}_{2} \mathrm{O}+\mathrm{K}_{2} \mathrm{O}\right)$; A sebagai jumlah persentase komposisi mineral bersifat asam $\left(\mathrm{SiO}_{2}+\mathrm{Al}_{2} \mathrm{O}_{3}\right.$ $+\mathrm{TiO}_{2}$ ); dan $\mathrm{S}$ sebagai nilai persentase total sulfur pada dry basis

- Bagi abu LRC: $R_{S}^{*}=\frac{B}{A}$

Tahap ketiga adalah menentukan klasifikasi slagging-nya berdasarkan jenis abu dan nilai slagging indice-nya:

- Bagi abu Bituminous: Low jika $\mathrm{R}_{\mathrm{s}}<0,6$; Medium jika 0,6 $<\mathrm{R}_{\mathrm{s}}<2$; High jika $2<\mathrm{R}_{\mathrm{s}}<2,6$; Severe jika $R_{s}>2,6$.

- Bagi abu LRC: Low jika $R_{S}^{*}<0,5$; Medium jika $0,5<R_{S}^{*}<1,0$; High jika $1,0<R_{S}^{*}<1,75$. Hasil pengolahan data dengan metode dari GWC dapat dilihat pada Tabel 2: 


\section{KILAT}

Vol. 10, No. 1, April 2021, P-ISSN 2089-1245, E-ISSN 2655-4925

DOI: https://doi.org/10.33322/kilat.v10i1.1176

Tabel 2. Hasil Pengolahan Data Menggunakan Metode dari GWC

\begin{tabular}{|c|c|c|c|c|c|c|c|c|c|c|c|c|}
\hline No. & 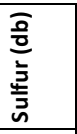 & O্刃் & 유 & $\stackrel{\text { 을 }}{\sum}$ & $\stackrel{\text { ○ }}{\simeq}$ & $\begin{array}{l}\text { O } \\
\text { तN }\end{array}$ & 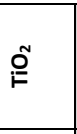 & 음 & $\frac{O_{\mathbb{N}}^{\infty}}{\mathbb{\alpha}}$ & Jenis Abu & $\begin{array}{l}\text { Slagging } \\
\text { Indice }\end{array}$ & $\begin{array}{c}\text { Klasifikasi } \\
\text { Slagging }\end{array}$ \\
\hline 1 & 0,25 & 10,11 & 15,59 & 1,78 & 0,39 & 0,56 & 0,83 & 44,83 & 18,11 & LRC & 0,45 & Low \\
\hline 2 & 0,25 & 10,45 & 17,99 & 5,90 & 0,32 & 0,29 & 0,92 & 37,9 & 18,82 & LRC & 0,61 & Medium \\
\hline 3 & 0,32 & 11,26 & 17,17 & 1,22 & 0,21 & 0,36 & 1,86 & 36,72 & 25,31 & LRC & 0,47 & Low \\
\hline 4 & 0,26 & 12,53 & 22,96 & 2,54 & 0,34 & 0,35 & 0,88 & 28,8 & 24,70 & LRC & 0,71 & Medium \\
\hline 5 & 0,33 & 10,41 & 22,90 & 1,46 & 0,35 & 0,58 & 2,08 & 25,38 & 25,74 & LRC & 0,67 & Medium \\
\hline 6 & 0,20 & 15,36 & 30,80 & 2,77 & 0,34 & 0,41 & 1,10 & 17,40 & 23,90 & LRC & 1,17 & High \\
\hline 7 & 0,21 & 13,41 & 27,51 & 2,21 & 0,36 & 0,47 & 0,97 & 26,96 & 18,79 & LRC & 0,94 & Medium \\
\hline 8 & 0,29 & 13,75 & 16,83 & 2,26 & 0,36 & 0,61 & 2,28 & 34,20 & 21,47 & LRC & 0,58 & Medium \\
\hline 9 & 0,20 & 14,28 & 20,39 & 2,61 & 0,41 & 0,45 & 0,78 & 35,27 & 17,40 & LRC & 0,71 & Medium \\
\hline 10 & 0,26 & 12,47 & 14,09 & 0,78 & 0,25 & 0,29 & 0,98 & 43,62 & 19,24 & LRC & 0,44 & Low \\
\hline 11 & 0,41 & 15,63 & 5,19 & 1,05 & 0,53 & 0,17 & 1,35 & 51,90 & 20,61 & LRC & 0,31 & Low \\
\hline 12 & 0,21 & 13,95 & 14,17 & 2,21 & 0,43 & 0,35 & 0,63 & 34,48 & 25,40 & LRC & 0,51 & Medium \\
\hline 13 & 0,21 & 11,91 & 10,28 & 2,61 & 0,30 & 0,38 & 0,58 & 38,96 & 24,33 & LRC & 0,4 & Low \\
\hline 14 & 0,25 & 12,96 & 10,18 & 2,25 & 0,22 & 0,26 & 1,12 & 41,77 & 23,98 & LRC & 0,39 & Low \\
\hline 15 & 0,30 & 9,82 & 9,94 & 2,50 & 0,39 & 0,37 & 1,26 & 45,53 & 25,02 & LRC & 0,32 & Low \\
\hline 16 & 0,34 & 1,67 & 15,71 & 1,28 & 0,21 & 0,39 & 1,27 & 35,68 & 24,01 & LRC & 0,32 & Low \\
\hline 17 & 0,26 & 15,57 & 13,99 & 2,15 & 0,41 & 0,36 & 0,93 & 36,81 & 20,41 & LRC & 0,56 & Medium \\
\hline 18 & 0,31 & 13,53 & 13,16 & 1,65 & 0,21 & 0,29 & 1,19 & 43,48 & 18,46 & LRC & 0,46 & Low \\
\hline 19 & 0,33 & 18,67 & 15,81 & 2,07 & 0,32 & 0,52 & 2,21 & 32,75 & 18,83 & LRC & 0,7 & Medium \\
\hline 20 & 0,32 & 19,17 & 14,07 & 2,52 & 0,42 & 0,74 & 2,04 & 32,70 & 20,20 & LRC & 0,67 & Medium \\
\hline 21 & 0,27 & 11,10 & 12,23 & 1,21 & 0,18 & 0,31 & 0,96 & 43,09 & 23,50 & LRC & 0,37 & Low \\
\hline 22 & 0,29 & 10,74 & 15,12 & 1,02 & 0,27 & 0,29 & 0,78 & 43,01 & 19,07 & LRC & 0,44 & Low \\
\hline 23 & 0,31 & 12,23 & 6,47 & 1,27 & 0,28 & 0,41 & 1,24 & 43,99 & 24,43 & LRC & 0,3 & Low \\
\hline 24 & 0,29 & 10,86 & 13,92 & 1,40 & 0,23 & 0,51 & 1,25 & 36,90 & 23,70 & LRC & 0,44 & Low \\
\hline 25 & 0,31 & 14,37 & 17,99 & 0,63 & 0,26 & 0,46 & 1,49 & 30,65 & 26,77 & LRC & 0,57 & Medium \\
\hline 26 & 0,19 & 10,42 & 27,91 & 5,86 & 0,38 & 0,71 & 0,61 & 23,61 & 16,12 & LRC & 1,12 & High \\
\hline 27 & 0,30 & 13,77 & 11,63 & 0,66 & 0,39 & 0,24 & 1,08 & 41,49 & 24,63 & LRC & 0,4 & Low \\
\hline 28 & 0,43 & 10,72 & 7,30 & 0,70 & 1,12 & 0,67 & 1,10 & 52,55 & 21,87 & LRC & 0,27 & Low \\
\hline 29 & 0,26 & 22,06 & 11,33 & 0,90 & 0,58 & 0,78 & 0,86 & 35,93 & 20,47 & LRC & 0,62 & Medium \\
\hline 30 & 0,28 & 13,48 & 15,35 & 0,72 & 0,28 & 0,46 & 1,28 & 42,05 & 20,04 & LRC & 0,48 & Low \\
\hline 31 & 0,30 & 7,14 & 11,17 & 1,12 & 0,29 & 0,72 & 0,67 & 54,60 & 17,42 & LRC & 0,28 & Low \\
\hline 32 & 0,37 & 10,51 & 12,79 & 1,17 & 0,90 & 0,66 & 0,44 & 45,77 & 22,54 & LRC & 0,38 & Low \\
\hline 33 & 0,31 & 11,63 & 16,88 & 0,96 & 0,35 & 0,50 & 1,69 & 34,71 & 25,57 & LRC & 0,49 & Low \\
\hline 34 & 0,27 & 12,64 & 12,89 & 0,52 & 0,39 & 0,40 & 0,84 & 38,10 & 27,05 & LRC & 0,41 & Low \\
\hline 35 & 0,28 & 10,46 & 22,99 & 6,96 & 0,24 & 0,62 & 1,47 & 29,57 & 20,15 & LRC & 0,81 & Medium \\
\hline 36 & 0,45 & 9,04 & 16,72 & 5,66 & 0,36 & 0,88 & 1,02 & 36,53 & 20,42 & LRC & 0,56 & Medium \\
\hline 37 & 0,30 & 6,92 & 24,64 & 1,37 & 0,31 & 0,74 & 0,94 & 40,75 & 16,70 & LRC & 0,58 & Medium \\
\hline 38 & 0,39 & 11,01 & 10,03 & 1,12 & 0,64 & 0,42 & 1,20 & 45,28 & 24,12 & LRC & 0,33 & Low \\
\hline 39 & 0,28 & 13,67 & 15,47 & 1,17 & 0,26 & 0,33 & 1,39 & 39,72 & 19,95 & LRC & 0,51 & Medium \\
\hline 40 & 0,29 & 10,77 & 12,21 & 0,77 & 0,29 & 0,22 & 0,70 & 42,22 & 24,47 & LRC & 0,36 & Low \\
\hline 41 & 0,27 & 14,30 & 16,87 & 0,93 & 0,23 & 0,24 & 1,62 & 39,75 & 19,86 & LRC & 0,53 & Medium \\
\hline 42 & 0,28 & 12,56 & 15,27 & 1,47 & 0,38 & 0,35 & 1,37 & 37,55 & 24,41 & LRC & 0,47 & Low \\
\hline 43 & 0,28 & 15,52 & 5,25 & 0,66 & 0,47 & 0,86 & 1,39 & 49,53 & 22,40 & LRC & 0,31 & Low \\
\hline 44 & 0,26 & 13,88 & 16,75 & 1,62 & 0,35 & 0,39 & 1,23 & 35,18 & 21,59 & LRC & 0,57 & Medium \\
\hline 45 & 0,28 & 6,21 & 2,45 & 0,54 & 0,94 & 1,47 & 1,50 & 55,43 & 29,31 & LRC & 0,13 & Low \\
\hline 46 & 0,28 & 13,91 & 18,21 & 1,27 & 0,30 & 0,35 & 1,20 & 41,71 & 16,58 & LRC & 0,57 & Medium \\
\hline 47 & 0,26 & 14,70 & 18,22 & 1,81 & 0,30 & 0,31 & 1,45 & 35,02 & 21,36 & LRC & 0,61 & Medium \\
\hline 48 & 0,51 & 12,77 & 5,88 & 0,48 & 0,71 & 0,35 & 0,76 & 49,94 & 24,21 & LRC & 0,27 & Low \\
\hline 49 & 0,26 & 12,84 & 15,34 & 1,97 & 0,30 & 0,50 & 1,41 & 39,87 & 19,32 & LRC & 0,51 & Medium \\
\hline 50 & 0,26 & 13,77 & 18,95 & 1,76 & 0,35 & 0,32 & 2,15 & 33,10 & 21,08 & LRC & 0,62 & Medium \\
\hline
\end{tabular}




\begin{tabular}{|c|c|c|c|c|c|c|c|c|c|c|c|c|}
\hline No. & $\begin{array}{l}\bar{a} \\
\frac{3}{0} \\
\frac{3}{3} \\
\text { n }\end{array}$ & 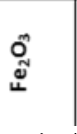 & ర్ల & 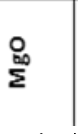 & 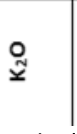 & 䣸 & $\stackrel{\sim}{\rho}$ & 은 & $\frac{0}{4}$ & Jen is Abu & $\begin{array}{l}\text { Slagging } \\
\text { Indice }\end{array}$ & $\begin{array}{c}\text { Klasifikasi } \\
\text { Slagging }\end{array}$ \\
\hline 51 & 0,37 & 11,97 & 6,37 & 0,75 & 0,81 & 0,35 & 1,37 & 47,34 & 24,68 & LRC & 0,28 & Low \\
\hline 52 & 0,27 & 13,41 & 16,79 & 1,98 & 0,27 & 0,33 & 1,39 & 38,92 & 19,23 & LRC & 0,55 & Medium \\
\hline 53 & 0,32 & 5,82 & 3,51 & 1,28 & 1,32 & 1,31 & 0,75 & 54,94 & 28,23 & LRC & 0,16 & Low \\
\hline 54 & 0,26 & 13,59 & 15,41 & 1,75 & 0,50 & 0,41 & 1,55 & 37,57 & 17,67 & LRC & 0,56 & Medium \\
\hline 55 & 0,30 & 14,39 & 19,52 & 1,60 & 0,33 & 0,44 & 1,87 & 36,06 & 21,81 & LRC & 0,61 & Medium \\
\hline 56 & 0,31 & 13,40 & 12,22 & 1,59 & 0,28 & 0,43 & 1,93 & 41,60 & 21,56 & LRC & 0,43 & Low \\
\hline 57 & 0,30 & 12,53 & 10,62 & 1,45 & 0,25 & 0,51 & 2,15 & 41,17 & 19,59 & LRC & 0,4 & Low \\
\hline 58 & 0,26 & 10,77 & 14,17 & 1,81 & 0,31 & 0,39 & 2,11 & 36,42 & 23,98 & LRC & 0,44 & Low \\
\hline 59 & 0,25 & 13,44 & 20,44 & 2,29 & 0,27 & 0,29 & 2,06 & 33,71 & 19,23 & LRC & 0,67 & Medium \\
\hline 60 & 0,40 & 20,12 & 8,01 & 1,05 & 0,41 & 0,59 & 2,05 & 41,70 & 21,73 & LRC & 0,46 & Low \\
\hline 61 & 0,27 & 12,65 & 18,83 & 1,65 & 0,42 & 0,46 & 1,90 & 33,47 & 23,41 & LRC & 0,58 & Medium \\
\hline 62 & 0,25 & 13,46 & 12,96 & 2,00 & 0,26 & 0,33 & 2,09 & 37,92 & 22,01 & LRC & 0,47 & Low \\
\hline 63 & 0,22 & 10,90 & 8,16 & 1,62 & 0,28 & 0,30 & 1,04 & 42,26 & 23,70 & LRC & 0,32 & Low \\
\hline 64 & 0,22 & 11,15 & 18,75 & 1,97 & 0,29 & 0,55 & 1,14 & 33,61 & 20,67 & LRC & 0,59 & Medium \\
\hline 65 & 0,27 & 12,37 & 14,77 & 2,06 & 0,29 & 0,57 & 1,46 & 36,86 & 20,87 & LRC & 0,51 & Medium \\
\hline 66 & 0,28 & 10,70 & 21,77 & 1,21 & 0,39 & 0,48 & 2,44 & 33,89 & 20,92 & LRC & 0,6 & Medium \\
\hline 67 & 0,29 & 11,45 & 19,37 & 1,77 & 0,43 & 0,62 & 2,38 & 33,14 & 22,94 & LRC & 0,58 & Medium \\
\hline 68 & 0,42 & 11,52 & 14,24 & 1,44 & 0,46 & 0,97 & 2,23 & 38,78 & 23,82 & LRC & 0,44 & Low \\
\hline 69 & 0,30 & 11,09 & 17,76 & 1,51 & 0,44 & 0,73 & 2,48 & 31,87 & 24,73 & LRC & 0,53 & Medium \\
\hline 70 & 0,32 & 11,14 & 20,41 & 1,97 & 0,51 & 0,59 & 2,04 & 32,22 & 22,95 & LRC & 0,61 & Medium \\
\hline 71 & 0,34 & 13,58 & 11,88 & 1,30 & 0,75 & 0,63 & 1,45 & 39,38 & 23,96 & LRC & 0,43 & Low \\
\hline 72 & 0,48 & 12,44 & 8,81 & 1,21 & 1,08 & 0,96 & 1,75 & 40,11 & 27,46 & LRC & 0,35 & Low \\
\hline 73 & 0,26 & 13,53 & 19,14 & 2,71 & 0,51 & 0,62 & 2,16 & 32,33 & 20,96 & LRC & 0,66 & Medium \\
\hline 74 & 0,28 & 13,64 & 18,54 & 2,50 & 0,50 & 0,67 & 2,11 & 31,97 & 23,47 & LRC & 0,62 & Medium \\
\hline 75 & 0,54 & 13,17 & 10,60 & 0,99 & 0,51 & 0,43 & 1,41 & 36,95 & 24,49 & LRC & 0,41 & Low \\
\hline 76 & 0,35 & 13,31 & 12,47 & 1,53 & 0,44 & 0,96 & 2,21 & 37,50 & 26,00 & LRC & 0,44 & Low \\
\hline 77 & 0,28 & 11,13 & 16,54 & 1,74 & 0,50 & 0,63 & 2,44 & 34,81 & 24,96 & LRC & 0,49 & Low \\
\hline 78 & 0,26 & 10,72 & 17,60 & 1,72 & 0,45 & 0,60 & 2,03 & 35,15 & 23,70 & LRC & 0,51 & Medium \\
\hline 79 & 0,33 & 12,62 & 14,43 & 1,09 & 0,47 & 0,66 & 1,28 & 37,46 & 22,79 & LRC & 0,48 & Low \\
\hline 80 & 0,37 & 14,76 & 15,71 & 1,68 & 0,56 & 0,62 & 1,68 & 33,92 & 22,69 & LRC & 0,57 & Medium \\
\hline 81 & 0,36 & 10,52 & 17,95 & 2,04 & 0,40 & 0,94 & 2,07 & 36,78 & 21,46 & LRC & 0,53 & Medium \\
\hline
\end{tabular}

\subsection{Analisis Statistik}

Analisis secara statistik menggunakan tools formula dari Microsoft Excel 2019 "countifs" untuk menghitung jumlah klasifikasi slagging masing-masing pada tiap-tiap jenis abu, kemudian dihitung persentasenya pada tiap-tiap jenis abu. Hasil analisis statistik pada tiap-tiap metode dapat dilihat pada Tabel 3 dan 4.

Tabel 3. Komposisi Klasifikasi Slagging dengan Metode dari B\&W

\begin{tabular}{|c|r|r|r|r|r|r|}
\hline \multirow{2}{*}{ Deskripsi } & \multicolumn{4}{|c|}{ Jenis Abu } & \multicolumn{2}{c|}{ Total } \\
\cline { 2 - 5 } & \multicolumn{2}{|c|}{ Lignitic Ash } & \multicolumn{2}{|c|}{ Bituminous Ash } & \multicolumn{2}{|c|}{} \\
\hline Jumlah Lot & 62 & $76,54 \%$ & 19 & $23,46 \%$ & 81 & $100,00 \%$ \\
\hline Klasifikasi Slagging & & & & & & \\
\hline - Low & 0 & $0,00 \%$ & 19 & $100,00 \%$ & 19 & $23,46 \%$ \\
\hline - Medium & 0 & $0,00 \%$ & 0 & $0,00 \%$ & 0 & $0,00 \%$ \\
\hline Low/Medium & $\mathbf{0}$ & $\mathbf{0 , 0 0 \%}$ & $\mathbf{1 9}$ & $\mathbf{1 0 0 , 0 0 \%}$ & $\mathbf{1 9}$ & $\mathbf{2 3 , 4 6 \%}$ \\
\hline - High & 0 & $0,00 \%$ & 0 & $0,00 \%$ & 0 & $0,00 \%$ \\
\hline - Severe & 62 & $100,00 \%$ & 0 & $0,00 \%$ & 62 & $76,54 \%$ \\
\hline High/Severe & $\mathbf{6 2}$ & $\mathbf{1 0 0 , 0 0 \%}$ & $\mathbf{0}$ & $\mathbf{0 , 0 0 \%}$ & $\mathbf{6 2}$ & $\mathbf{1 0 0 , 0 0 \%}$ \\
\hline
\end{tabular}


Vol. 10, No. 1, April 2021, P-ISSN 2089-1245, E-ISSN 2655-4925

DOI: https://doi.org/10.33322/kilat.v10i1.1176

Tabel 4. Komposisi Klasifikasi Slagging dengan Metode dari GWC

\begin{tabular}{|c|c|c|c|c|c|c|}
\hline \multirow{3}{*}{\begin{tabular}{|l|}
\multicolumn{1}{|c}{ Deskripsi } \\
Jumlah Lot \\
\end{tabular}} & \multicolumn{4}{|c|}{ Jenis Abu } & \multirow{2}{*}{\multicolumn{2}{|c|}{ Total }} \\
\hline & \multicolumn{2}{|c|}{ LRC Ash } & \multicolumn{2}{|c|}{ Bituminous Ash } & & \\
\hline & 81 & $100,00 \%$ & 0 & $0,00 \%$ & 81 & $100,00 \%$ \\
\hline \multicolumn{7}{|l|}{ Klasifikasi Slagging } \\
\hline - Low & 41 & $50,62 \%$ & 0 & \#DIV/0! & 41 & $50,62 \%$ \\
\hline - Medium & 38 & $46,91 \%$ & 0 & \#DIV/0! & 38 & $46,91 \%$ \\
\hline Low/Medium & 79 & $97,53 \%$ & $\mathbf{0}$ & \#DIV/0! & 79 & $97,53 \%$ \\
\hline - High & 2 & $2,47 \%$ & 0 & \#DIV/0! & 2 & $2,47 \%$ \\
\hline - Severe & 0 & $0,00 \%$ & 0 & \#DIV/0! & 0 & $0,00 \%$ \\
\hline High/Severe & 2 & $2,47 \%$ & $\mathbf{0}$ & \#DIV/0! & 2 & $2,47 \%$ \\
\hline
\end{tabular}

\section{HASIL DAN PEMBAHASAN}

Penentuan slagging indice dan klasifikasi slagging pada kedua metode tersebut memiliki kesamaan yaitu jika abu batu baranya digolongkan sebagai abu bituminous. Sedangkan, pada abu jenis lainnya (abu LRC dan abu Lignit), penentuannya sama sekali berbeda.

Pada metode dari B\&W, jenis abu ditentukan berdasarkan formula sehingga batu bara jenis LRC yang diterima oleh PLTU bisa memiliki kemungkinan dua jenis abu: Lignit atau Bituminous. Oleh karena itu, menurut metode dari B\&W pada tahun 2018 didapatkan bahwa abunya yang tergolong Lignit sebanyak 62 lot (76,54\%) dan tergolong Bituminous sebanyak 19 lot (23,46\%). Batu bara yang memiliki abu Lignit, seluruhnya diklasifikasikan Severe menurut metode dari B\&W. Namun, pada batu bara yang memiliki abu Bituminous, seluruhnya diklasifikasikan Low menurut metode dari B\&W. Oleh karena itu, secara statistik 62 lot batu bara yang diterima selama tahun 2018 tergolong bukan boiler friendly dari aspek potensi slagging-nya dan 19 lot batu bara tergolong boiler friendly.

Pada metode dari GWC, jenis abu ditentukan berdasarkan klasifikasi batu baranya, sehingga batu bara jenis LRC yang diterima oleh PLTU secara langsung digolongkan sebagai abu LRC. Oleh karena itu, menurut metode dari GWC pada tahun 2018 didapatkan bahwa seluruh batu bara yang diterima tergolong abu LRC. Sebanyak 41 lot batu bara diklasifikasikan potensi slagging Low dan 38 lot batu bara diklasifikasikan potensi slagging Medium menurut metode dari GWC. Namun, sebanyak 2 lot batu bara diklasifikasikan potensi slagging High._Oleh karena itu, secara statistik 79 lot $(97,53 \%)$ batu bara yang diterima selama tahun 2018 tergolong boiler friendly dari aspek potensi slagging-nya dan 2 lot $(2,47 \%)$ batu bara tergolong bukan boiler friendly.

\section{KESIMPULAN DAN SARAN}

Hasil penelitian ini telah membuktikan bahwa metode klasifikasi slagging dari B\&W terhadap batu bara LRC sangat cenderung mengklasifikasikan potensi slagging-nya menjadi Severe. Sebaliknya, metode dari GWC sangat cenderung mengklasifikasikan potensi slagging-nya menjadi Low/Medium. Secara kuantitatif, tulisan ini telah menunjukkan hasil bahwa metode dari GWC menunjukkan 79 lot abunya (97,53\%) memiliki klasifikasi Low dan Medium dan 2 lot abunya $(2,47 \%)$ memiliki klasifikasi $\mathrm{High}$; metode dari B\&W menunjukkan 19 lot abunya $(23,46 \%)$ memiliki klasifikasi Low dan 62 lot abunya (76,54\%) memiliki klasifikasi Severe.

Terkait dengan hal tersebut di atas, penulis menyampaikan saran supaya dilakukan penelitian lebih lanjut untuk mempelajari korelasi antara klasifikasi slagging tersebut di atas dan kondisi aktual kejadian slagging pada boiler pada kurun waktu yang sama. Selain itu, untuk keperluan pembelian batu bara seluruh PLTU milik PLN se-Indonesia dan untuk meningkatkan efisiensi penyediaan 
energi listrik, maka diperlukan penelitian lebih lanjut tentang skema penyesuaian harga dengan prinsip win-win solution antar kedua belah pihak.

\section{UCAPAN TERIMAKASIH}

Penulis mengucapkan terima kasih kepada PT PLN (Persero) UIK Sumatera Bagian Selatan UPK Sebalang dan Institut Teknologi PLN yang telah memberi dukungan yang membantu pelaksanaan penelitian hingga terwujud.

\section{DAFTAR PUSTAKA}

[1] PT PLN (Persero), Rencana Usaha Penyediaan Tenaga Listrik PT PLN (Persero) 2019-2028, Jakarta: PT PLN (Persero), 2019.

[2] PT PLN (Persero), Laporan Keuangan Konsolidasian Untuk Tahun-tahun yang Berakhir pada Tanggal 31 Desember 2017 dan 2016, Jakarta: PT PLN (Persero), 2018.

[3] PT PLN (Persero), Laporan Keuangan Konsolidasian Untuk Tahun-tahun yang Berakhir pada Tanggal 31 Desember 2018 dan 2017, Jakarta: PT PLN (Persero), 2019.

[4] PT PLN (Persero), Laporan Keuangan Konsolidasian Untuk Tahun-tahun yang Berakhir pada Tanggal 31 Desember 2019, 2018, dan 2017, Jakarta: PT PLN (Persero), 2020.

[5] S. Balakrishnan, R. Nagarajan and K. Karthick, "Mechanistic modeling, numerical simulation and validation of slag-layer growth in a coal-fired boiler," Energy, vol. 81, pp. 462-470, 3 2015.

[6] W. J. Shi, L. X. Kong, J. Bai, J. Xu, W. C. Li, Z. Q. Bai and W. Li, Effect of CaO/Fe2O3 on fusion behaviors of coal ash at high temperatures, vol. 181, 2018.

[7] N. J. Sophia and H. Hasini, "Investigation on Coal Slagging Characteristics and Combustion Behaviour in Furnace," in MATEC Web of Conference, Malaysia, 2017.

[8] The Babcock \& Wilcox Company, Steam/ Its Generation and Use, 41 ed., USA: The Babcock \& Wilcox Company, 2005.

[9] George Waterhouse Consultants Ltd., GWC Coal Handbook, United Kingdom: George Waterhouse Consultants Ltd., 1991.

[10] ASTM International, ASTM D2234 / D2234M-16, Standard Practice for Collection of a Gross Sample of Coal, West Conshohocken, PA: ASTM International, 2016.

[11] ASTM International, ASTM D6609-08(2015), Standard Guide for Part-Stream Sampling of Coal, West Conshohocken, PA: ASTM International, 2015.

[12] ASTM International, ASTM D4239-17, Standard Test Method for Sulfur in the Analysis Sample of Coal and Coke Using High-Temperature Tube Furnace Combustion, West Conshohocken, PA: ASTM International, 2017.

[13] ASTM International, ASTM D3682-13, Standard Test Method for Major and Minor Elements in Combustion Residues from Coal Utilization Processes, West Conshohocken, PA: ASTM International, 2013.

[14] ASTM International, ASTM D1857 / D1857M-17, Standard Test Method for Fusibility of Coal and Coke Ash, West Conshohocken, PA: ASTM International, 2017. 